\title{
E-learning in Mongolian Higher Education
}

Suvdmaa Tuul, Otgontugs Banzragch, and Tsogzolmaa Saizmaa

National University of Mongolia

\begin{abstract}
This paper reviews the e-learning course development in selected universities of Mongolia and attempts to classify the e-learning programs that are in practice at the tertiary education level in the country. The given paper uses both secondary and primary sources.

The authors determined what factors influence e-learning type classification and how time consuming is e-learning in course development stage in comparison to that of face-to-face learning? Methods such as computation using threshold values, $k$-means clustering, and comparison of means using paired $t$ tests were used. Furthermore, comparison of means was used to validate the factors.

In conclusion, authors deliver recommendations based on analysis lessons learned for further development. This research has practical implications for higher education managers to make informed decisions.
\end{abstract}

Keywords: e-learning, Mongolia, higher education, $k$-means clustering, means comparison

\section{Introduction}

Higher education has become increasingly important on the national agenda and has undergone profound mutations and reforms worldwide over the past decades, as portrayed in the "Organisation for Economic Co-operation and Development (OECD) review of tertiary education policies" (Organisation for Economic Co-operation and Development, 2008). There is a substantial market for higher education in Mongolia. In the 2014 to 2015 academic year, 13,360 lecturers and administrators provided service to 178,295 students out of which 19,065 were master's students and 3,391 were PhD students at 101 higher educational institutions (Ministry of Education and Science, 2015). Mongolia ranks seventh internationally in the share of GDP (9.0\%) allocated to education, and its education law guarantees that at least $20 \%$ of the government budget is spent on education 
(Government of Mongolia, 2006). However Mongolian higher education receives only $12 \%$ of that amount (Asian Development Bank Institute, 2010).

Global trends in higher education include the expansion of higher education systems, wider participation, emergence of new players, more diverse profiles of institutions, programmes and students, continuing advancement and rapid integration of new technology, greater internationalisation, increasing pressures on costs and new modes of financing, growing emphasis on market forces (competition and signalling mechanisms), new modes of governance stressing performance, and quality and accountability (Tremblay, Lalancette, \& Roseveare, 2012).

E-learning is a global phonemon over the last decades in higher education. Likewise, E-learning initiatives can be a cost-effective method of delivering higher education in Mongolia with its vast territory and sparse population. There were numerous e-learning materials developed over the last couple of years. However, there is a limited research on e-learning in Mongolia.

Mongolia has adequate infrastructure to develop e-learning. This achievement is a result of the EMongolia National Program 2005-2012 which aimed to become one of the most Information and Communications Technology (ICT) developed 10 countries in the Asia pacific region. Out of 144 nations, Mongolia ranked $61^{\text {st }}$ in ICT use, $83^{\text {rd }}$ in higher education and training, and $80^{\text {th }}$ in Internet access in schools in the 2014-2015 Global Competitiveness Report (World Economic Forum, 2015). A study by the International Trade Union (ITU) and the United Nations Educational, Scientific, and Cultural Organization (UNESCO; 2013) indicates that in Mongolia, $16.4 \%$ of population use internet and $16 \%$ of households have an Internet connection. In 2012, Mongolia ranked per 100 inhabitants, 10oth of 183 counties in fixed broadband penetration, 61st of 128 countries in mobile broadband penetration (ITU \& NESCO, 2013). Furthermore, Mongolia ranked $92^{\text {nd }}$ out of 166 economies worldwide in the information development index in 2013 (ITU, 2014).

\section{Research Methodology}

The study puts emphasis on the developmental stage of an e-learning course. This study is carried out to investigate the following research questions:

1. What types of e-learning exists in Mongolia, and how can we classify them?

2. What factors influence the e-learning classification? What has been the motivation or incentive to develop e-learning programs at universities?

3. How labor intensive is e-learning in comparison to face-to-face learning in the developmental stage? In order to measure and compare we have broken down the task into 2 questions. How much time do faculty members dedicate to e-course development? How much is it in comparison to face-to-face learning?

4. In what ways has the legislative and regulatory framework coordinated e-learning?

A mixed method research design (Creswell, 2012) including the collection and quantitative analysis of questionnaire data followed by qualitative analysis of focus group interview data was used to address the research questions. The study utilized purposeful sampling when selecting the population. 
The methodology for investigating the first three research questions is survey. Initially, the authors contacted the respective universities to get information about lecturers who developed e-learning materials or tools. The information about lecturers that have developed the e-learning course were retrieved from the following three sources: university records of acceptance of e-course, author presentations in the respective e-learning thematic conferences, and snowball-star, a heuristic method which asks the professionals about their fellows (Patton, 2001). Because snowball sampling is hardly representative of the larger study population, it is primarily used for exploratory purposes. The reason for choosing the snowball method is that there are no statistics in the national or institutional level regarding e-learning.

For the purposes of this article we will use the following terms (Allen \& Seaman, 2011):

- Traditional method of teaching occurs when content is delivered face-to-face to students.

- Web facilitated courses, are those courses that have $1 \%$ to $29 \%$ of the course content delivered online. It may use course management system (CMS) or web pages to post the syllabus and assignments

- Blended or hybrid courses are differentiated from online and face-to-face courses as having anywhere from $30 \%$ to $80 \%$ of the course content delivered online. Even though blended learning has significant proportion its content is delivered online, it has number of face-toface meetings.

- Online courses are defined as those courses with at least $80 \%$ of the course content delivered online.

\section{Instrument Development and Data Analysis}

The survey was designed to collect quantitative and qualitative information about the profile of university teachers training on e-learning and estimated time spent on developing e-learning courseware.

The survey had three sections consisting of 14 questions on demographics, 15 questions on e-learning and three questions on face-to-face learning was developed. There were four open ended and 28 multi-choice questions with 77 items. Afterwards, a pilot test was conducted on two lecturers followed by revision of three survey questions.

The study was conducted from November 25, 2014 to February 20, 2015. The invitation to participate in the survey was distributed to 419 university lecturers via email. These lecturers present the population that developed e-learning course in higher education. The letter of informed consent explained the objective and expected outcome of the survey. In total 58 university lecturers participated in the survey on a voluntary basis and therefore the return rate was $13.84 \%$. The low return rate was due to the fact that survey respondents were not compensated and participated on voluntary basis.

The data from the Google forms were imported into Microsoft Excel 2010 then into SPSS version 18. Frequency was calculated for each of the questions and some outliers were removed. Afterwards, we clustered using the same items separately using the $k$-means approach which was used to measure 
and group items by minimizing the square of the Euclidean distance. Comparison of means was executed in order to find out the factors that influenced e-learning classification.

The methodology for the fourth research question was document analysis and focus group interviews with a purposive sub-sample of the participants. Interview protocol was developed. A series of interviews was carried out based on an interview protocol. Fourteen institutions including four public universities and research institutes were visited and 10 resources persons were interviewed at their offices such as the former director of an e-school, the project leader of the Mongolian University of Science and Technology (MUST), IT department director of the Mongolian University of Life Science (MULS), a researcher in e-learning, the team leader of the school of business and economy, NUM, and the team leader of the project of MUST.

This helped the researcher understand the strengths, weaknesses, opportunities, and threats in the development of e-learning in tertiary education. Focus group interviews in educational research use purposive sub-samples to provide specific data on peoples' views and attitudes (Creswell, 2012). Interview data were used to further clarify the quantitative data provided by the whole sample.

The logic of the criterion approach means that you select participants that meet predetermined criteria (Patton, 2001). A major benefit to criterion and snowball sampling is that it ensures an equivalent analysis.

First of all, the respondents were asked to choose their detailed research fields in the questionnaire. The fields of science were classified according to "the Frascati manual on the proposed standard practice for surveys on research and experimental developmental survey" (Organisation for Economic Co-operation and Development, 2007). Afterwards, it was merged into the main fields of science.

The second means of collecting data and information is by reviewing and analyzing documents in the forms of laws, prevailing government regulations and guidelines, as well as university bylaws, internal regulations and guidelines that appertain to e-learning, intellectual property rights, and performancemeasuring guidelines for faculty members at both sectoral and institutional levels.

\section{Demographics}

The survey respondents had following characteristics. By gender, $67.2 \%$ of the respondents were women. Out of a total of 5642 faculty member of Mongolian higher education, 52.89\% are women (Ministry of Education and Science, 2015). The 33.3\% of respondents were senior lecturers, 22.8\% were lecturers, and $17.5 \%$ were associate professors. According to the national aggregates, $38.21 \%$ are lecturers, $23.72 \%$ are senior lecturers, and $\mathbf{1 1 . 3 3 \%}$ are associate professors.

The lecturers who developed e-learning were experienced faculty members as they worked eight to 22 years with a mean of 17.19 years of employment, taught at their current university from three to 22 years with mean of 13.71 years, and taught their current course from three to 22 years with mean of 7.17 years.

The lecturers chose their respective science fields. The science fields were classified according to the OECD Frascati manual (Organisation for Economic Co-operation and Development, 2007). The 37.9\% of the respondents were teaching in each of the natural sciences, engineering, and technology, whilst $15.5 \%$ were majoring social sciences, and $6.9 \%$ in humanities. 
A competency is the ability to meet individual and social demands successfully, or to carry out a task or activity. The ability to use knowledge and information interactively is one of the key competences in the twenty-first century (Organisation for Economic Co-operation and Development, 2002). Likewise, one of the key competencies of university lecturers is the ability to use new technology. Faculty development plays an important role in building this competency. The majority of respondents (74.1\%) said they participated in e-learning training: $34.5 \%$ of respondents were involved in one to three days training, $27.5 \%$ were trained four to 10 days, $6.9 \%$ were trained up to one month, and only $5.1 \%$ were trained more than one semester. Funding for training of $60.3 \%$ of respondents was provided by the university or faculty. Lecturers have interest in e-learning as $8.6 \%$ of them used private funding. The fact that a quarter or $25.9 \%$ of respondents were not involved in training and that $36.2 \%$ of respondents said they do not use any learning theory to develop e-learning, highlights the importance of faculty re-training on e-learning.

The question 11 asked the respondents about Learning Management System (LMS) that they use at universities. In total, $57.9 \%$ of respondents said their universities have locally developed LMS in the Mongolian language, $17.5 \%$ informed that they use other systems such as MOODLE or MOOCs, 10.5\% notified that LMS is under construction, and $14 \%$ stated that their universities have no LMS in place.

\section{Results}

The survey instrument and interview presented following results.

\section{Why the lecturers develop e-learning?}

The majority of respondents said the purpose to develop e-learning was to direct knowledge building (37.9\%), provide students with information (36.2\%), and engage in discussion or e-forums (13.8\%). Some respondents said they applied cognitivist (10.3\%), behaviorist (6.9\%), and constructivist (3.4) approaches to develop e-learning.

\section{The Classification of E-learning}

In our research we considered that one semester consists of 16 weeks. To classify e-learning types, we choose Question 24 which asked the respondents how comprehensive is the e-learning that they have developed? The question is composed of 11 components such as (a) curriculum, (b) lecture, (c) seminar and lab works, (d) self-check quiz, (e) mid-term exam and assignments, (f) course book and other supporting printed materials, (g) supporting photo gallery, audio and video, (h) glossary, (i) research database, (j) past exams, (k) guide and help for e-learners. First of all, we asked the respondents to identify the number of developed units in intervals such as 1, 2, 3-5, 6-10, 11-15, equal or more than 16 units or 1 semester. Afterwards, authors decoded range intervals into scale to conduct classification analysis, compare means and regression. The scaled values are 1, 2, 4, 8, 13, and 16 respectively.

Initially, integrated_e_learning value is created after totaling and averaging scaled values of the first six components. We summed the number of items of the five components such as lecture, seminar and lab work, self-assessment quiz, mid-term exam and assignments, and course book and other supporting printed materials. We excluded curriculum for further analysis as every course had this component. Components such as a supporting photo gallery, and audio and video material; a glossary; 
a research database; past exams; a guide and help for e-learners were excluded from further computation as they were too detailed, received few responses, and were course specific. Then, an imputed variable called E-learning Class was created. In order to classify the courses, three approaches were applied such as computation using threshold values (Allen \& Seaman 2011), $k$-means with one variable and $k$-means with five variables.

First, we classified the measurements using threshold values by Allen and Seaman (2011). We consider only 16 weeks being full e-learning courses for a semester or $100 \%$. The classification results are presented on Table 1.

The second method used to group was $k$-means clustering. The cluster number was set to three. Afterwards, it classified the 58 measurements into three types such as Web facilitated, blended or hybrid, and online. It is interesting that six responses fall into an interval between [80; 82,5], whereas 80 is a bottom line to online learning. Therefore, we can conclude that maybe we should narrow the online learning bottom line to 85 in this case.

The third method used to explore classification was the $k$-means with five independent variables. We found that $22.4 \%$ of the courses are Web facilitated courses, $74.1 \%$ are blended courses, and only $3.4 \%$ meets the requirement of online courses.

Table 1

Comparative Classification of E-learning

\section{Method}

\begin{tabular}{|c|c|c|c|c|c|c|}
\hline \multirow[b]{2}{*}{ Groups } & \multicolumn{2}{|c|}{$\begin{array}{l}\text { Computation } \\
\text { using threshold } \\
\text { values }\end{array}$} & \multicolumn{2}{|c|}{$\begin{array}{l}k \text {-means with one } \\
\text { variable }\end{array}$} & \multicolumn{2}{|c|}{$k$-means with five independent variables } \\
\hline & $n$ & Mean & $n$ & Mean & $n$ & Cluster centers \\
\hline $\begin{array}{l}\text { Web } \\
\text { facilitated }\end{array}$ & 12 & 9.06 & 12 & 9.06 & 13 & $(12.5 ; 6.25 ; 18.75 ; 12.5 ; 6.25)$ \\
\hline Blended & 15 & 63.25 & 20 & 67.87 & 43 & $(100 ; 87.5 ; 87.5 ; 75 ; 81.25)$ \\
\hline Online & 31 & 96.04 & 26 & 98.79 & 2 & $(100 ; 56.25 ; 100 ; 100 ; 100)$ \\
\hline Conclusion & $\begin{array}{l}\text { No } \\
\text { it } \\
\text { thr } \\
\text { nu }\end{array}$ & $\begin{array}{c}\text { cable as } \\
\text { simple }\end{array}$ & $\begin{array}{l}\text { No } \\
\text { we } \\
\text { ave } \\
\text { ha } \\
\text { blu }\end{array}$ & $\begin{array}{l}\text { icable as } \\
\text { led and } \\
\text { This may } \\
\text { caused }\end{array}$ & $\begin{array}{l}\text { App } \\
\text { reas } \\
\text { mee }\end{array}$ & $\begin{array}{l}\text { as the methodology is } \\
\text { Furthermore, cluster results } \\
\text { terview. }\end{array}$ \\
\hline
\end{tabular}

Note. Computation using threshold values by Allen and Seaman (2011). $n=$ the number of courses.

The latter approach, $k$-means clustering with five independent variables, is applicable as the methodology is reasonable and cluster results matched with the interview results. Therefore, we accepted this cluster.

\section{Factors Affecting E-learning Classification}

Next, we tried to determine factors that influence the e-learning classification. In order to determine which factors affect e-learning classification we used means comparison. Therefore, e-learning classification was coded into 1 (Web facilitated), 2 (blended) and 3 (online). 
In the third method, where we used $k$-means with five independent variables, the factors displayed in Table 2 have influence on e-learning classification. The significance levels were achieved by using analysis of variance (ANOVA) tests.

Table 2

Factors Affecting E-learning Classification

\begin{tabular}{lccc}
\hline Factor & $\boldsymbol{F}$-value & $\boldsymbol{d} \boldsymbol{f}$ & $\boldsymbol{p}$-value \\
\hline Position & 2.44 & 6 & .037 \\
LMS & 2.75 & 3 & .050 \\
Master degree courses & 3.30 & 2 & .049 \\
Team composition & 2.68 & 4 & .041 \\
Expected lifetime of e- & 3.15 & 5 & .015 \\
$\quad$ course & & & .045 \\
Marking down & 2.66 & 4 & \\
$\quad$ assignments in face- & & & \\
$\quad$ to-face learning & & & \\
\hline
\end{tabular}

Senior lecturers and lecturers, who have the highest workload, had the highest tendency to develop elearning. Professors, associate professors, and department heads had an average tendency to develop e-learning. Assistant lecturers and researchers (other) had a lower tendency to develop e-learning.

Lecturers of the universities with in-house developed LMS have a tendency to develop e-learning. Some Details of statistical analysis are shown in Annex 1.

The report on masters degree courses showed an upward trend. As the course specialization level increases, the tendency to develop e-course increases. The more specialized the course, the greater the tendency was to shift to e-learning.

Team composition was essential in the development of e-learning. Team leadership was significant.

The expected lifetime of e-learning reflects in positive way. The study showed that e-learning was used for an average of four to five years with a mean of 1.81 .

We conducted regression analysis, as the mean of "master degree courses" showed trend. The following relationship was found as a result of regression. The constant was 1.095 and unstandardized coefficient was 0.26 (see Equation 1). This means that as master's course subjects shifted from basic to professional to specialized, the lecturer's motivation or willingness to incorporate e-learning increased by $26 \%$.

Image 1: regression analysis

$$
\mathrm{y}=1.095+0.26 \mathrm{x}+\varepsilon ; \quad \mathrm{R}^{2}=0.16
$$

where y thetendency to develop e - learning,

$\mathrm{x}$ is the level of master course specialization,

$\varepsilon$ is residual 
Table 3

Regression Analysis Coefficients ${ }^{\mathrm{a}}$

\begin{tabular}{|c|c|c|c|c|c|}
\hline \multirow[t]{2}{*}{ Model } & \multicolumn{2}{|c|}{$\begin{array}{l}\text { Unstandardize } \\
\text { d Coefficients }\end{array}$} & $\begin{array}{c}\text { Standardized } \\
\text { Coefficients }\end{array}$ & \multirow[b]{2}{*}{$\begin{array}{c}t- \\
\text { statistic }\end{array}$} & \multirow[b]{2}{*}{$\begin{array}{c}P \\
\text { value }\end{array}$} \\
\hline & B & $\begin{array}{l}\text { Std. } \\
\text { Error }\end{array}$ & Beta & & \\
\hline (Constant) & 1.095 & .264 & & 4.141 & .000 \\
\hline $\begin{array}{l}\text { For which educational level do } \\
\text { you use e-learning? [master] }\end{array}$ & .262 & .101 & .406 & 2.588 & .014 \\
\hline
\end{tabular}

Note. ${ }^{a}$ Dependent Variable: Cluster Number of Case. ${ }^{b}$ Predictors: (Constant), 19. For which educational level do you use e-learning? [master]

Table 4

Results of the ANOVA a test

\begin{tabular}{cccccc}
\hline Model & $\begin{array}{c}\text { Sum of } \\
\text { Squares }\end{array}$ & df & $\begin{array}{c}\text { Mean } \\
\text { Square }\end{array}$ & $\begin{array}{c}\boldsymbol{F} \text { - } \\
\text { statistic }\end{array}$ & $\boldsymbol{p}$-value \\
\hline Regression & 1.440 & 1 & 1.440 & 6.700 & $.014^{\mathrm{b}}$ \\
Residual & 7.310 & 34 & .215 & & \\
Total & 8.750 & 35 & & & \\
\hline
\end{tabular}

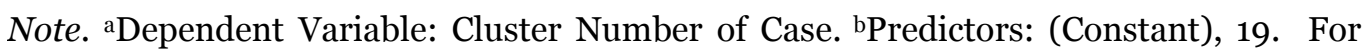
which educational level do you use e-learning? [master]

Only masters by coursework are practiced in Mongolia. There is scarce financial assistantship for graduate students and majority of them are part time. The family and work commitments have to be addressed alongside studies. Therefore, the e-learning programs are in high demand for adults to overcome time and space limitations.

This is in line with survey findings where 19 tertiary education institutions from 13 countries participated (Center for Educational Research and Innovation, 2005). The survey concluded that whole award programs with a relevant online presence were more common at the postgraduate level to meet the demand of experienced learners wishing to combine work, family, and study.

\section{E-course Development Time vs. preparation to Face-to-Face Learning}

In order to calculate the time devoted to each of the activities, the mean values were calculated.

For e-learning, the most time consuming activities were the development of student e-learning manuals (12.92 days), development of trial versions of e-courses (12.49 days), and improvement based on trial results (12.19 days). On average, lecturers spent 295.5 days to develop an e-course. This is 
longer than that of the design (one to two months) and production (two to six months) of MOOCs (Hochschulrektorenkonferenz, June 2014).

In face-to-face learning, the most time consuming activities were curriculum development (2.5 days) and developing final exams (2.5 days). On average, lecturers spent 90.35 days for face-to-face teaching.

\section{The Interview and Document Analysis Results}

Document analysis revealed that there is lack of policy and regulation. Article 8.1 of the Law on Education of Mongolia states that formal education can be in day, evening, and external forms. The universities conduct distance learning using this article. The only document in force is the Policy on ICT in Education Sector 2012-2016 approved by order A24 of the Minister of Education, Culture and Science on September 20, 2012. In the framework of the second objective to integrate learning with ICTs, the following activities are planned: develop standard requirements for the e-learning courses from teaching and ICT perspectives; establish independent organization in charge of e-learning, teaching, and learning; adopt creative commons license and enable open source courseware; policy support for higher education institutions that are developing open courses, enabling access to open course wares, developing distance learning infrastructure for common use; and introduce mobile learning. The policy has well developed monitoring indicators, where 10 out of 50 are relevant to the International Standard Classification on Education (ISCED) level 6 education.

Documents such as ICT Vision up to 2010, National Program on Distance Education 2002-2010, The Introduction of ICT into Education Sector up to 2010, E-Mongolia 2005-2012 have expired. The legislative framework needs to coordinate the market demand and global trend. The clear and concise recognition of e-learning, its quality assurance is essential to new regulation. As outlined in a comparative study of quality assurance in Asian distance education, Mongolia needs to set quality assurance criteria for both face-to-face and distance learning institutions (Jung, Wong, Li, Sanjaa, \& Belawati, 2011).

The interview revealed lecturers' assessment, future direction, thoughts, and concerns about elearning.

One lecturer described it that "The whole distance learning programs rely on single provision from law on education. To introduce e-learning with credits in higher education institutions, government shall issue detailed regulation.” [D4]

One lecturer revealed that "my master students work at remote mining site still can attend the class, do the lab work and submit assignments. This is a huge benefit for the energy engineers." [D6]

A team leader of the project from Mongolian university of science and technology (MUST) informed that some university lecturers felt sensitive over their intellectual property rights. To deal with it MUST organized series of workshops on e-learning and intellectual property rights and issued recommendations on adoption of creative commons. [D5] Authors believe that faculty members hiring guide and fixed term employment contract shall reflect intellectual property rights of universities. 
"The e-learning institute said that 'because we engineering university, we used mainly internal resources. Lecturers provided the curriculum, supplied materials and supervised execution of students, who did technical work for the e-learning. On the other hand, students did some technical assignments by working on e-learning projects" [D1]

One manager said that "Leadership is essential for e-learning development. It is win-win situation where faculty members, students and university benefitted from this initiative" [D2].

MULS said that development of e-learning serves as one of the performance indicators for the faculty members.

Table 5 presents a summary of university policies on e-learning. 
Table 5

Summary of University Policies on E-learning

\begin{tabular}{|c|c|c|c|c|c|c|c|c|}
\hline $\begin{array}{l}\text { Name of } \\
\text { Institution }\end{array}$ & $\begin{array}{l}\text { Number } \\
\text { of } \\
\text { Students }\end{array}$ & $\begin{array}{l}\text { Number } \\
\text { of } \\
\text { Master } \\
\text { Students }\end{array}$ & $\begin{array}{l}\text { E-learning } \\
\text { Policy or } \\
\text { Guideline }\end{array}$ & $\begin{array}{l}\text { IPRs Policy or } \\
\text { Strategy }\end{array}$ & LMS & $\begin{array}{l}\text { Center of Faculty } \\
\text { Development }\end{array}$ & Financial Incentives & Note \\
\hline $\begin{array}{l}\text { Mongolian } \\
\text { National } \\
\text { University }\end{array}$ & 22,514 & 3,362 & No & $\begin{array}{l}\text { Yes, University } \\
\text { guideline on } \\
\text { IPRs, August 31, } \\
2012\end{array}$ & $\begin{array}{l}\text { SiSi- } \\
\text { locally } \\
\text { developed } \\
\text { system }\end{array}$ & No & $\begin{array}{l}\text { The article } 16 \text { of the Guideline of } \\
\text { Faculty Member Position, } \\
\text { Performance Evaluation states that } \\
\text { student center shall determine the } \\
\text { workload of the lecturer who } \\
\text { developed e-learning (approved by } \\
\text { Presidential Order \#652 } \\
\text { of December 7, 2012, annex 4). }\end{array}$ & $\begin{array}{l}\text { It is an unclear } \\
\text { regulation. We } \\
\text { have not been able } \\
\text { to find any } \\
\text { practice in place. }\end{array}$ \\
\hline $\begin{array}{l}\text { Mongolian } \\
\text { University } \\
\text { for } \\
\text { Science } \\
\text { and } \\
\text { Technolog } \\
\text { y }\end{array}$ & 23,110 & 2,044 & $\begin{array}{l}\text { E-learning } \\
\text { program } \\
\text { approved in } \\
2007\end{array}$ & $\begin{array}{l}\text { Yes, University } \\
\text { guideline on } \\
\text { IPRs, October } \\
23,2012\end{array}$ & $\begin{array}{l}\text { UniMIS } \\
\text { locally } \\
\text { developed } \\
\text { system }\end{array}$ & $\begin{array}{l}\text { Yes, E-learning } \\
\text { institute }\end{array}$ & $\begin{array}{l}\text { From } 2011 \text { to } 2012 \text { up to } 500,000 \\
\text { tugrics per course were given to } \\
\text { lecturers. }\end{array}$ & $\begin{array}{l}\text { There were } 285 \text { e- } \\
\text { tools developed } \\
\text { from 2007 to } 2012 \\
\text { (Төрбат, 2012). }\end{array}$ \\
\hline $\begin{array}{l}\text { Mongolian } \\
\text { University } \\
\text { of Life } \\
\text { Sciences }\end{array}$ & 11,507 & 2,158 & $\begin{array}{l}\text { E-learning } \\
\text { program } \\
\text { adopted in } \\
2009\end{array}$ & $\begin{array}{l}\text { Has extension } \\
\text { center since } \\
2006 \text { for IPRs. }\end{array}$ & & No & Part of teaching duty & $\begin{array}{l}\text { Development of e- } \\
\text { learning serves as } \\
\text { a performance } \\
\text { indicator. }\end{array}$ \\
\hline $\begin{array}{l}\text { Mongolian } \\
\text { National } \\
\text { University } \\
\text { of Health } \\
\text { Sciences }\end{array}$ & 8,139 & 1,317 & No & $\begin{array}{l}\text { Yes, University } \\
\text { guideline on } \\
\text { IPRs and } \\
\text { technology } \\
\text { transfer, } 2013\end{array}$ & & $\begin{array}{l}\text { No. IT department } \\
\text { provides } \\
\text { assistance }\end{array}$ & Part of teaching duty & $\begin{array}{l}\text { Applied in the } \\
\text { medical } \\
\text { practitioner or } \\
\text { intern studies. }\end{array}$ \\
\hline $\begin{array}{l}\text { Mongolian } \\
\text { University } \\
\text { of } \\
\text { Education }\end{array}$ & 12,128 & 1,138 & & Unknown & Moodle & $\begin{array}{l}\text { No. provided } \\
\text { training to faculty } \\
\text { members via } \\
\text { cooperation with } \\
\text { MUST }\end{array}$ & $\begin{array}{l}\text { Competition on the best e-learning } \\
\text { material was organized in } \\
\text { November 2014. In finals there } \\
\text { were } 18 \text { e-tools selected (Mongolian } \\
\text { State University of Education). }\end{array}$ & $\begin{array}{l}\text { Intends to } \\
\text { establish distance } \\
\text { learning center for } \\
\text { in-service teacher } \\
\text { training. }\end{array}$ \\
\hline
\end{tabular}




\section{Conclusion}

E-learning in higher education in Mongolia is in its early stage of development. We determined what factors influence the e-learning type classification and how time consuming e-learning is in the course development stage in comparison to that of face-to-face learning?

Three approaches such as computation using threshold values (Allen \& Seaman, 2011), $k$-means clustering with one variable and $k$-means clustering with five independent variables were used to classify courses. The latter approach is applicable as the methodology is reasonable and cluster results matched with the results of the interview.

We attempted to classify them using $k$-means with five independent variables and found that $22.4 \%$ of the courses are Web facilitated courses, $74.1 \%$ are blended courses, and only $3.4 \%$ meet the requirement of online courses.

A study limitation is that key stakeholders such as students have not participated in the study. The study represents a snapshot of the higher education sector. The differences between universities and fields of science were explored. However, due to the small sample size it did not show a significant difference. It could be subject to future research.

Afterwards, we tried to determine the factors that influence e-learning classification. The variables such as lecturers' position, LMS, master's degree courses out of all levels of tertiary education, team leadership, expected lifetime of e-course and marking down assignments in face-to-face learning showed significant influence to e-learning classification. Out of the variables, only masters's degree course level proved to be significant with a coefficient of 0.26 and a constant of 1.095. This means that as master's course subjects shifted from basic, professional to specialized, the lecturer's motivation or willingness increased by $26 \%$.

The intellectual property rights of universities shall be enforced. At a national level, there shall be a clear and concise article on recognition of e-learning as a form of learning and to ensure e-learning degree acceptance in the law on higher education. The legislative framework needs to coordinate the market demand and global trend and shall be enforced in sectoral and institutional levels. The quality accreditation is an essential step for future development.

At an institutional level, the majority of e-courses were initiated by lecturers. Only very few universities have centers for teaching excellence or e-learning institutes that can provide training and hands-on assistance.

\section{References}

Asian Development Bank Institute. (2010). Economic shocks and higher education reform: People's Republic of China, Mongolia, and Viet Nam. Mahwah, New Jersey; London: Lawrence Erlbaum.

Allen, I. E., \& Seaman, J. (2011). Going the distance: Online education in the United States, 2011. Wellesley, MA: Babson Survey Research Group. 
Center for Educational Research and Innovation (CERI). (2005). Elearning in tertiary education: Where do we stand? , OECD publishing.

Creswell, J. W. (2012). Educational research: Planning, conducting and evaluating quantitative and qualitative research (4th ed.). Boston, MA: Pearson Education.

Government of Mongolia, (2006). The State budget, Retrieved from http://www.legalinfo.mn

Hochschulrektorenkonferenz. (2014, June). The potential and problems of MOOCs: MOOCs in the context of digital teaching. Bonn, Germany: German Rectors' Conference.

International Trade Union. (2014). Measuring the information society report. Geneva Switzerland: ITU.

International Trade Union \& the United Nations Educational, Scientific \& Cultural Organization. (Sep., 2013). The state of broadband 2013: Universalizing broadband. Geneva, Switzerland: The Broadband Commission for Digital Development.

Jung, I., Wong, T. M., Li, C., Sanjaa, B., \& Belawati, T. (2011). Quality assurance in Asian distance education: Diverse approaches and common culture. The International Review of Research in Open and Distributed Learning, 12(6), 63-83. Retrieved from http://www.irrodl.org/index.php/irrodl/article/view/991/1953.

Ministry of education and science. (2015, February 1). Statistical bulletin of education and science sector. Retrieved from http://www.meds.gov.mn/HigherSta1415.

Mongolian State University of Education. (n.d.). Retrieved on January 3, 2015, from http://msue.edu.mn/index.php?module=menu\&cmd=content\&id=1274\&menu id=121.

Organisation for Economic Co-operation and Development. (2002). Definition and selection of key competencies: theoritical and conceptual foundations. Neuchatel: Swiss Federation Statistical office.

Organisation for Economic Co-operation and Development. (2007). Revised field of science and technology (fos) classification in the Frascati manual (DSTI/EAS/STP/NESTI(2006)19/FINAL). OECD publishing .

Organisation for Economic Co-operation and Development. (2008). Tertiary education for knowledge society. Paris: OECD Publishing.

Patton, M. Q. (2001). Qualitative evaluation and research methods (3 ed.). Newbury Park, CA: Sage.

Төрбат, Р. (2012). ШУТИС-ийн Е-Нээлттэй сургуулийн оюуны өмчийн зохицуулалт. ШУТҮЗ: Эрдэм шинжилгээний байгууллагын оюуны өмчийн асуудлууд, ШУТИС-ийн хэвлэлийн газар.

Tremblay, K., Lalancette, D., \& Roseveare, D. (2012). Assessment of higher education learning outcomes: Feasibility study report volume 1. Location: OECD. 
Tuul, Banzragch, and Saizmaa

World Economic Forum. (2015). The global competitiveness report 2014-2015. Geneva, Switzerland: Publisher.

\section{Athabasca \\ University}

(c) (i) 


\section{Annex 1: Details of Statistical Analysis}

Table 2.1

Position's Influence to e-Learning Classification

Cluster Number of Case

\begin{tabular}{|l|l|l|l|}
\hline 4. Position & Mean & N & Std. Deviation \\
\hline Head of department & 1.60 & 5 & .548 \\
Professor & 1.86 & 7 & .690 \\
Associate professor & 1.70 & 10 & .483 \\
Senior lecturer & 1.95 & 20 & .394 \\
Lecturer & 1.92 & 13 & .277 \\
Associate Lecturer & 1.00 & 1 & - \\
Other & 1.00 & 2 & .000 \\
Total & 1.81 & 58 & .476 \\
\hline
\end{tabular}

Lecturers of the universities have in house developed LMS have tendency to develop e-learning.

Table 2.2

Having LMS has Influence to e-Learning Classification

Cluster Number of Case

\begin{tabular}{|c|c|c|c|}
\hline $\begin{array}{l}\text { 11. Does your university have learning management } \\
\text { system? }\end{array}$ & Mean & $\mathrm{N}$ & Std. Deviation \\
\hline Under development & 1.33 & 6 & .516 \\
\hline Local or Mongolian developed & 1.82 & 33 & .465 \\
\hline University has no LMS & 2.00 & 8 & .535 \\
\hline Other & 1.90 & 10 & .316 \\
\hline Total & 1.81 & 57 & .480 \\
\hline
\end{tabular}

The report on Master degree courses showed upward trend. As the course specialization level increases, the tendency to develop e-course increases. The more specialized is the course, the tendency to shift e-learning increases.

Table 2.3

Master's Degree Course has Influence to e-Learning Classification

Cluster Number of Case

\begin{tabular}{|l|l|l|l|}
\hline $\begin{array}{l}\text { 19. For which educational level do you use e-learning? } \\
\text { [master }]\end{array}$ & Mean & Std. Deviation \\
\hline General academic & 1.33 & 6 & .516
\end{tabular}


Professional

Special

1.67

1.88

Total

1.75

\begin{tabular}{|l|l|}
6 & .516 \\
24 & .448 \\
36 & .500
\end{tabular}

Team composition was essential in the development of e-learning. The team leadership was significant.

Table 2.4

Team Work Influence to e-Learning Classification

Cluster Number of Case

\begin{tabular}{|l|r|r|r|}
\hline 23. Would you introduce your team? & Mean & N & $\begin{array}{c}\text { Std. } \\
\text { Deviation }\end{array}$ \\
\hline No & 1.78 & 41 & .475 \\
1 person & 1.86 & 14 & .363 \\
3 people & 3.00 & 1 & $\cdot$ \\
4 people & 2.00 & 1 & $\cdot$ \\
More than 5 people & 1.00 & 1 & $\cdot$ \\
Total & 1.81 & 58 & .476 \\
\hline
\end{tabular}

Expected lifetime of e-learning reflects in positive way. Study shows that e-learning will be used for average of 4-5 years with the total mean of 1.81 .

Table 2.5

The Expected Number of Years to Use e-Learning Material

Cluster Number of Case

\begin{tabular}{|l|r|r|r|}
\hline $\begin{array}{l}\text { 27. What is the lifetime of the e- } \\
\text { learning? }\end{array}$ & Mean & $\mathrm{N}$ & \multicolumn{1}{c|}{$\begin{array}{c}\text { Std. } \\
\text { Deviation }\end{array}$} \\
\hline 1-2 years & 1.29 & 7 & .488 \\
2-3 years & 1.75 & 12 & .452 \\
4-5 years & 1.96 & 23 & .475 \\
6-7 years & 2.00 & 6 & .000 \\
8-9 years & 1.60 & 5 & .548 \\
More than 10 years & 2.00 & 4 & .000 \\
Total & 1.81 & 57 & .480 \\
\hline
\end{tabular}

Table 2.6

Marking Down Assignment in Traditional Learning has Influence to e-Learning Classification 
Cluster Number of Case

\begin{tabular}{|l|r|r|r|}
\hline $\begin{array}{l}\text { 30. How much of your time do you } \\
\text { devote in the face-to face learning } \\
\text { for the following activities? }\end{array}$ & Mean & $\mathrm{N}$ & Std. Deviation \\
[Marking down the assignments] & & & \\
\hline $1-4$ hours & 1.33 & 3 & .577 \\
$4-8$ hours & 1.64 & 14 & .497 \\
$1-2$ days & 2.09 & 11 & .302 \\
$2-3$ days & 1.93 & 14 & .475 \\
more than 4 days & 1.83 & 6 & .408 \\
Total & 1.83 & 48 & .476 \\
\hline
\end{tabular}

